\title{
Die nalatenskap van die Griekse taal en letterkunde
}

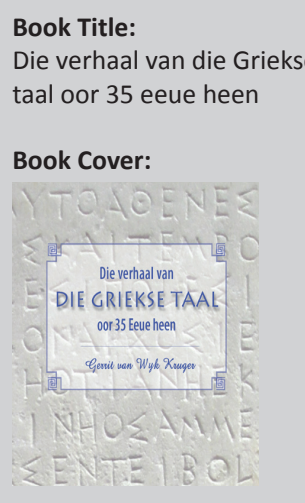

Author:

Gerrit van Wyk Kruger

ISBN:

978-1-928357-29-2 (print);

978-1-928357-30-8 (e-book)

Publisher:

African SUN MeDIA, 2017,

R540*

*Book price at time of review

$$
\square
$$

Review Title:

Die nalatenskap van die Griekse taal en letterkunde

Reviewer:

Gert J.C. Jordaan ${ }^{1}$ (D)

Affiliation:

${ }^{1}$ Faculty of Theology,

North-West University,

Potchefstroom, South Africa

Corresponding author:

Gert Jordaan,

gert.jordaan@nwu.ac.za

How to cite this book review:

Jordaan, G.J.C, 2019, 'Die

nalatenskap van die Griekse

taal en letterkunde', In die

Skriflig 53(1), a2534. https://

doi.org/10.4102/ids.

v53i1. 2534

\section{Copyright:}

C 2019. The Authors.

Licensee: AOSIS. This work

is licensed under the

Creative Commons

Attribution License.

\section{Read online:}

Hierdie boek kan beskou word as ' $n$ 'lewenswerk' wat Gerrit van Wyk Kruger geskryf het aan die einde van sy lang en geseënde loopbaan as die eerste professor in Nuwe-Testamentiese Grieks aan die Universiteit van Stellenbosch. Dit is 'n publikasie waarin hy sy liefde vir die Griekse taal en letterkunde op so 'n wyse openbaar dat die leser die rykdom van insigte wat hy bereik het, en inligting wat hy oor jare se saamleef met die taal versamel het, met hom kan deel. As sodanig is dit inderdaad 'n merkwaardige publikasie.

Ter inleiding skryf Kruger dat hy die boek só saamgestel het dat dit byna soos 'n roman gelees kan word. Die boek is egter met soveel inligting gelaai wat soms met soveel besonderhede bespreek word, dat daar seker min lesers sal wees wat die boek werklik as 'n roman sal ervaar. Tog is die inligting en besonderhede vir die filologie so belangrik, en word die historiese verbande met soveel insig en skerpsinnigheid gelê dat ' $n$ toegewyde leser groot genot daaruit behoort te put.

Die verhaal van Grieks waarin die wel en weë van die taal vertel word, strek vanaf oer-Grieks (1500 v.C.) tot moderne Grieks. Die leser word eers in die ontwikkeling van die Griekse alfabet en skryfwyse ingelei, en daarna aan die verskillende skrywers voorgestel wat deur die eeue tot die Griekse letterkunde bydraes gelewer het. Dit begin by die epiese werke van Homeros en gaan dan verder na die goue era van Klassieke Grieks tydens die vyfde eeu v.C., waarin beroemde skrywers soos Thoukudides, Sophokles, Euripides en Aristophanes die Griekse letterkunde uitgebou het. Sonder om hulle werke een vir een te bespreek, word die enorme bydraes van die klassieke skrywers op die Griekse taal, styl en letterkunde kortliks genoem en in perspektief geplaas.

'n Groot deel van die boek (145 bladsye) word aan die ontwikkeling van Grieks in die Hellenistiese era gewy, juis omdat dit die tydperk is waarin Koinê-Grieks, die Grieks van die Nuwe Testament, ontstaan het. Hoofstuk 5 bevat ' $n$ grondige uiteensetting en verklaring van die hoofkenmerke van die Nuwe-Testamentiese Grieks, sonder om die Nuwe-Testamentiese skrywers of hulle individuele styl afsonderlik te bespreek. Tog word ander skrywers van die Hellenistiese tydperk, die sogenaamde literêre Koinê-skrywers soos Polubius, Strabo, Ménandros en Theophrastos deegliker bespreek. Hoewel elkeen se lewensverhaal en werke net kortliks beskryf word, is dit steeds vir die leser waardevol, aangesien min Nuwe-Testamentici in hulle publikasies aan hierdie kontemporêre literatuur aandag gee.

Op dieselfde wyse word in Hoofstuk 6 'n oorsig oor die Bisantynse Griekse letterkunde gegee. Die werk van Middeleeuse skrywers wat vir die meeste Nuwe-Testamentici onbekend of hoogstens blote name was, word in hierdie hoofstuk op 'n verstaanbare wyse bespreek. So word dit ook gedoen met betrekking tot skrywers uit die tydperk ná die Europese Renaissance, en in Hoofstuk 7, moderne Griekse skrywers.

'n Mooi perspektief wat deurgaans na vore kom, is die ooreenkoms tussen die geskiedenis van die Griekse taal (die oudste taal met 'n letterkunde) en die geskiedenis van Afrikaans (die jongste taal met 'n letterkunde) - spesifiek die stryd om amptelike erkenning van beidie die tale om aanvaar te word as ' $n$ taal wat algemeen gepraat word.

In die geheel is dit ' $n$ boeiende boek om te lees - weliswaar nie soos ' $n$ roman nie, maar meer soos 'n ensiklopedie wat die leser stadig, met noukeurige aandag stukkie vir stukkie kan proe en deurwerk. Ten spyte van die neiging tot hoë akademiese taal wat plek-plek opduik en die enkele drukfoute wat hier en daar deurgeglip het, is die verhaal van die Griekse taal soos deur prof. Gerrit van Wyk Kruger vertel, die moeite werd om te lees. Dit word van harte aanbeveel vir elkeen wat in die studie van die Griekse taal belangstel. 